\title{
Relationship between serum HBsAg level, HBV DNA level, and peripheral immune cells in patients with chronic hepatitis $B$ virus infection
}

This article was published in the following Dove Press journal:

Hepatic Medicine: Evidence and Research

15 November 2010

Number of times this article has been viewed

\author{
RM Mukherjee' \\ P Balkumar Reddy' \\ Jyothi Arava' \\ PN Rao \\ Sasikala Mitnala' \\ R Gupta ${ }^{2}$ \\ DN Reddy ${ }^{2}$
}

'Asian Health Care Foundation, ${ }^{2}$ Asian Institute of Gastroenterology, Somajiguda, Hyderabad, India
Correspondence: RM Mukherjee Institute of Basic Sciences, Asian Health Care Foundation, 6-3-66I, Somajiguda, Hyderabad 500082, India

$\mathrm{Tel}+914023378888$

Fax +91 4023324255

Email rathinmukh@gmail.com
Background: The chronicity of hepatitis B virus (HBV) infection is attributed to inappropriate functioning of cell-mediated immunity. Besides the importance of measuring serum HBV DNA and HBV surface antigen (HBsAg) as markers of viral replication and exposure, respectively, studies regarding their influence on immune cell status in chronic HBV infection are still scarce. Because such studies of chronic HBV patients have not been reported for India, we attempted to evaluate the relationship between serum concentrations of HBsAg, HBV DNA, and percentage of immune cells in peripheral blood of Indian subjects with chronic HBV infection.

Methods: Thirty-one HbsAg-positive subjects were evaluated for serum $\mathrm{HBe}$ antigen ( $\mathrm{HBeAg})$, anti-HBe, and alanine transferase status by standard enzyme-linked immunosorbent assay (ELISA) and biochemical procedures. Serum HBV DNA level was determined by real-time TaqMan ${ }^{\circledR}$ polymerase chain reaction assay. Serum HBsAg level was measured by a third-generation sandwich ELISA kit. Peripheral immune cell profiling was done by multifluorometric flow cytometry analysis, for which 21 healthy subjects were included as controls.

Results: The majority (93.5\%) of the study subjects were HBeAg-negative and anti-HBeAgpositive. Mean viral load, HBsAg, and alanine transferase levels were $4.20 \pm 1.96 \log$ copies $/ \mathrm{mL}$, $5.98 \pm 4.62 \log \mathrm{IU} / \mathrm{mL}$, and $74.5 \pm 110 \mathrm{IU} / \mathrm{mL}$, respectively. In comparison with controls, total $\mathrm{T}$ cell and cytotoxic $\mathrm{T}$ cell populations were significantly $(P<0.05)$ reduced in HBV-infected subjects, while the status of B cells, natural killer cells, T helper cells, and ratio of T helper to cytotoxic cells remained unaltered.

Conclusion: Suppression of the peripheral cytotoxic $\mathrm{T}$ cell population in chronic HBeAg-negative chronic HBV infection is influenced by increased viral load. Serum HBsAg concentration appeared independent of serum HBV DNA level and immune cell status. Nonelevation of natural killer cell and $\mathrm{T}$ helper cell numbers in subjects harboring lower to moderate HBV loads is further indicative of noninduction of innate as well as a coordinated adaptive immune response favoring chronicity of the disease.

Keywords: hepatitis B virus, HBsAg quantitation, viral load, peripheral lymphocytes, chronic HBV infection

\section{Introduction}

The complexity of the pathogenesis of hepatitis B virus (HBV) has not been clarified properly as yet. The host's response through cell-mediated immunity rather than a direct cytopathic effect of the virus is said to be responsible for the damage to infected hepatocytes. ${ }^{1}$ Peripheral blood mononuclear cells containing an aggregate of immune-competent cells, including subsets of T lymphocytes, natural killer cells, and lymphokine-activated killer T cells, are thought to play an important role in the persistence or control of HBV infection. ${ }^{2,3}$ Moreover, a strong association between cytotoxic T cells, liver cell damage, 
and HBV clearance has also been demonstrated. ${ }^{4,5}$ Intrahepatic compartmentalization of HBV-specific CD8 cells, with a progressive decline in human leukocyte antigen (HLA)-DR activation markers on these cells, has been reported in resolving acute $\mathrm{HBV}$ infection. ${ }^{6}$ Apart from the antiviral response on the host's part, measurement of serum HBV DNA, being a marker of viral persistence and replication, is the common tool used to monitor treatment response in HBV infection. Besides the variable treatment outcome in patients with chronic HBV treated with nucleoside/nucleotide analogs and interferons, a high response rate in patients having a low baseline level of $\mathrm{HBV}$ DNA has been demonstrated. ${ }^{7,8}$ The prime determinant of the likelihood of liver injury and its intensification to cirrhosis has therefore been attributed to the interplay of the host immune response and the replication ability of the virus. Recent studies of HBV pathogenesis in animal models demonstrated that enhanced recruitment of virus-specific $\mathrm{T}$ lymphocytes into the liver cells is critical for the pathogenesis of both HBV infection and hepatocellular carcinoma., ${ }^{9,10}$ On the other hand, detection of HBsAg as the first serologic marker of the disease is done routinely, the persistence of which beyond six months signifies chronic infection, while its disappearance from the circulation marks closure to cure outcome of HBV infection. The quantitative measurement of HBsAg gained momentum in recent times due to its importance as a predictor of early virologic response to antiviral therapy, ${ }^{11-13}$ as well as helping to distinguish disease status in chronic HBV patients. ${ }^{14}$ Furthermore, quantitative measurement of serum HBsAg is indicated as a surrogate marker for viral covalently closed circular DNA and intrahepatic HBV DNA, ${ }^{11}$ which are believed to maintain the replicative form of HBV DNA, hence maintain the chronic form of the disease. Because reports regarding the relationship between serum HBV DNA, serum HBsAg levels, and the numeric status of circulating immunocompetent cells in Indian chronic HBV patients are far from adequate, the present study explores the possible relationship between these parameters in Indian subjects with chronic HBV infection.

\section{Methods}

\section{Subjects}

Thirty-one subjects who attended the outpatient's department of the Asian Institute of Gastroenterology, Hyderabad, during the period June 2009 to January 2010, were positive for HBsAg for more than six months, and had clinical features of chronic HBV, were prospectively included as study group patients. Twenty-one voluntary blood donors devoid of HBsAg in their sera served as controls for the lymphocyte estimation study. Informed consent was obtained from both the control and study group subjects, and the study was approved by the Institutional Ethics Committee.

\section{Serologic and biochemical parameters}

The serum HBeAg and anti-HBe status of the subjects were determined by commercial enzyme-linked immunosorbent assay (ELISA) kits (Amar-EASE, Taiwan) as per the manufacturer's instructions. Serum aspartate transferase and alanine transferase levels were ascertained by an automated clinical biochemistry analysis system (Randox, Oceanside, CA).

\section{Quantitation of serum HBV DNA and genotyping}

Extraction of viral DNA from patient's sera was done using the High Pure System Viral Nucleic Acid kit (Roche Molecular Systems, Belleville, NJ) as per the manufacturer's instructions. Amplification and subsequent quantification of extracted DNA were performed by the COBAS ${ }^{\circledR}$ TaqMan $^{\circledR}$ HBV test using a COBAS TaqMan 48 Analyzer (Roche Molecular Systems) which has a lower limit detection of 6 IU (35 copies) of HBV DNA/mL. HBV genotypes were determined using an inhouse nested polymerase chain reaction assay involving type-specific primers to generate respective genotype-specific amplicons. ${ }^{15}$

\section{Quantitation of serum $\mathrm{HBsAg}$}

Serum concentration of HBsAg was measured by a sandwich ELISA kit (Alpha Diagnostic International, San Antonio, TX) as per the manufacturer's instructions. This kit meets the requirements for a third-generation test upon testing against the Food and Drug Administration reference panel. Performance of this kit was compared with a commercial test kit (Abbot Auszyme II, Abbott Laboratories, Abbott Park, IL) and assumed to detect all possible combinations of HBsAg subtypes (adw, adr, ayw, ayr), having a lower limit of sensitivity of $0.3 \mathrm{ng} / \mathrm{mL}$, as per the manufacturer's declaration. For convenience, $\mathrm{HBsAg}$ concentrations measured in $\mathrm{ng} / \mathrm{mL}$ were converted to $\mathrm{IU} / \mathrm{mL}$, considering that $0.15 \mathrm{ng} / \mathrm{mL}$ of HBsAg is equivalent to $350 \mathrm{IU} / \mathrm{mL} .^{16}$

\section{Quantitation of peripheral blood lymphocytes}

The following antibodies were divided in two panels for fluorescence-activated cell sorter (FACS) analysis. A threecolor direct immunofluorescence reagent TriTEST CD4 fluorescein isothiocyanate (FITC)/CD8 phycoerythrin $(\mathrm{PE}) / \mathrm{CD} 3$ peridinin chlorophyll protein (PerCP) was used 
to identify and determine the absolute counts of mature human T lymphocytes (CD3+), helper/inducer (CD3+CD4+) $\mathrm{T}$ lymphocytes, and suppressor/cytotoxic (CD3+ CD8+) $\mathrm{T}$ lymphocytes, and a four-color direct immunofluorescence reagent MultiTEST CD3 FITC/CD16+ CD56 PE/CD45 PerCP/CD19 allophycocyanin was employed to identify and determine the percentages and absolute counts of mature human T (CD3+), natural killer (CD3-CD16+ CD56+), and B (CD3- CD19+) lymphocytes in erythrocyte-lyzed whole blood. The reagents employ fluorescence triggering, allowing direct fluorescence gating of the lymphocyte population to reduce contamination by unlyzed or nucleated red blood cells in the gate. Matched isotype antibodies were used for control staining. All reagents were obtained from Becton Dickinson (San Jose, CA) and used as per the manufacturer's instructions. Three- and four-color analysis was performed by gating 10,000 $\pm 20,000$ events on acquisition of respective cellular expression for each analysis using a FACS Caliber or FAC Scan (Becton Dickinson) flow cytometer.

\section{Statistical analysis}

Descriptive statistics (mean, median, standard deviations, and interquartile ranges [IQR]), Student's $t$-test, and Fisher's Exact tests were performed as and where applicable using SPSS software, version 13.0 (SPSS, Inc., Chicago, IL). A value of $P<0.05$ was considered statistically significant.

\section{Results}

Of 31 mostly male (96\%) patients, 93.5\% were negative for $\mathrm{HBeAg}$ and positive for anti-HBe. Genotype D was found to be predominant $(83.8 \%)$, followed by genotype A $(16.2 \%)$. A significantly lowered total T cell $(P=0.02)$ and cytotoxic $\mathrm{T}$ cell population $(P=0.018)$ was evident in HBV-infected subjects in comparison with the healthy controls (Table 1). The median values and IQR of total $\mathrm{T}$ cells for control and study subjects observed were 69.1 $(\mathrm{IQR}=9.1)$ and $66.9(\mathrm{IQR}=7.55)$, respectively, while the median values of cytotoxic $\mathrm{T}$ cells for control and study subjects were $27.2(\mathrm{IQR}=13.1)$ and $24.6(\mathrm{IQR}=10.2)$, respectively (Figure 1). No significant alteration of cytotoxic to helper T cell ratios was apparent upon comparing the control $($ median $=1.07 ; \mathrm{IQR}=0.39)$ and patient $($ median $=1.11$; $\mathrm{IQR}=0.68)$ groups. The median viral load (log copies $/ \mathrm{mL})$ and HBsAg $(\log \mathrm{IU} / \mathrm{mL})$ levels noted in the patient group were $3.91(\mathrm{IQR}=2.10)$ and $4.59(\mathrm{IQR}=1.04)$. As depicted in Table 2, upon grouping of patients on the basis of viral load $(<2000 \mathrm{IU} / \mathrm{mL})$ in comparison with controls, while the natural killer cell status remain unaltered, a significant drop in the total T cell population was observed in the group of patients having a viral load $<2000 \mathrm{IU} / \mathrm{mL}(P=0.02)$, as well as in the group of patients having a viral load $>2000 \mathrm{IU} / \mathrm{mL}(P=0.05)$. Interestingly, compared with control subjects, the population of cytotoxic T cells reduced significantly $(P=0.04)$ in patients having a higher viral load $(>2000 \mathrm{IU} / \mathrm{mL})$ than in the patients having a lower viral load $(<2000 \mathrm{IU} / \mathrm{mL})$, while no alteration in the helper $\mathrm{T}$ cell population was encountered in either group (Table 2). No significant differences were found in immune cell profile and HBsAg levels between the patients having lower or higher viral loads, but both alanine transferase and aspartate transferase levels increased significantly $(P<0.02)$ with increasing viral load (Table 3 ).

\section{Discussion}

The types of cell-mediated responses expressed in the early stages of HBV infection can influence the subsequent outcome. In chronic $\mathrm{HBV}$ infection, the $\mathrm{HBV}$-specific $\mathrm{T}$ cell responses

Table I Characteristics of control and HBV-infected subjects

\begin{tabular}{|c|c|c|c|}
\hline Parameters & Controls $(n=21)$ & Patients $(n=3 I)$ & $P$ value \\
\hline Age (years; mean \pm SD) & $29.20 \pm 7.91$ & $36.0 \pm 12.70$ & ND \\
\hline Male (\%) & 76.1 & 96.7 & ND \\
\hline $\mathrm{T}$ cells $($ mean $\pm \mathrm{SD})$ & $68.98 \pm 5.74 *$ & $64.1 \pm 7.35^{*}$ & $0.02 *$ \\
\hline B cells (mean $\pm S D$ ) & $14.82 \pm 4.87$ & $16.2 \pm 6.26$ & 0.41 \\
\hline Natural killer cells (mean \pm SD) & $17.19 \pm 4.45$ & $16.89 \pm 5.72$ & 0.841 \\
\hline $\mathrm{T}_{c}$ cells $($ mean $\pm \mathrm{SD})$ & $31.69 \pm 12.65^{*}$ & $24.97 \pm 6.47^{*}$ & $0.018^{*}$ \\
\hline $\mathrm{T}_{\mathrm{H}}$ cells $($ mean $\pm \mathrm{SD})$ & $30.9 \pm 5.28$ & $30.94 \pm 5.19$ & 0.98 \\
\hline $\mathrm{T}_{\mathrm{H}}: \mathrm{T}_{\mathrm{c}}($ mean $\pm \mathrm{SD})$ & $1.114 \pm 0.413$ & $1.328 \pm 0.462$ & 0.089 \\
\hline Viral load (log copies/mL; mean \pm SD) & ND & $4.20 \pm 1.96$ & ND \\
\hline HbsAg (log IU/mL; mean \pm SD) & ND & $5.98 \pm 4.62$ & ND \\
\hline $\operatorname{ALT}(\mathrm{IU} / \mathrm{mL} ;$ mean $\pm \mathrm{SD})$ & ND & $74.5 \pm 110$ & ND \\
\hline
\end{tabular}

Note: *Statistically significant (Student's unpaired $t$-test).

Abbreviations: ND, not detected; SD, standard deviation; HBV, hepatitis B virus; ALT, alanine transferase; HbsAg, hepatitis B surface antigen; $T$, cytotoxic T cells; $\mathrm{T}_{\mathrm{H}}$, helper $\mathrm{T}$ cells. 


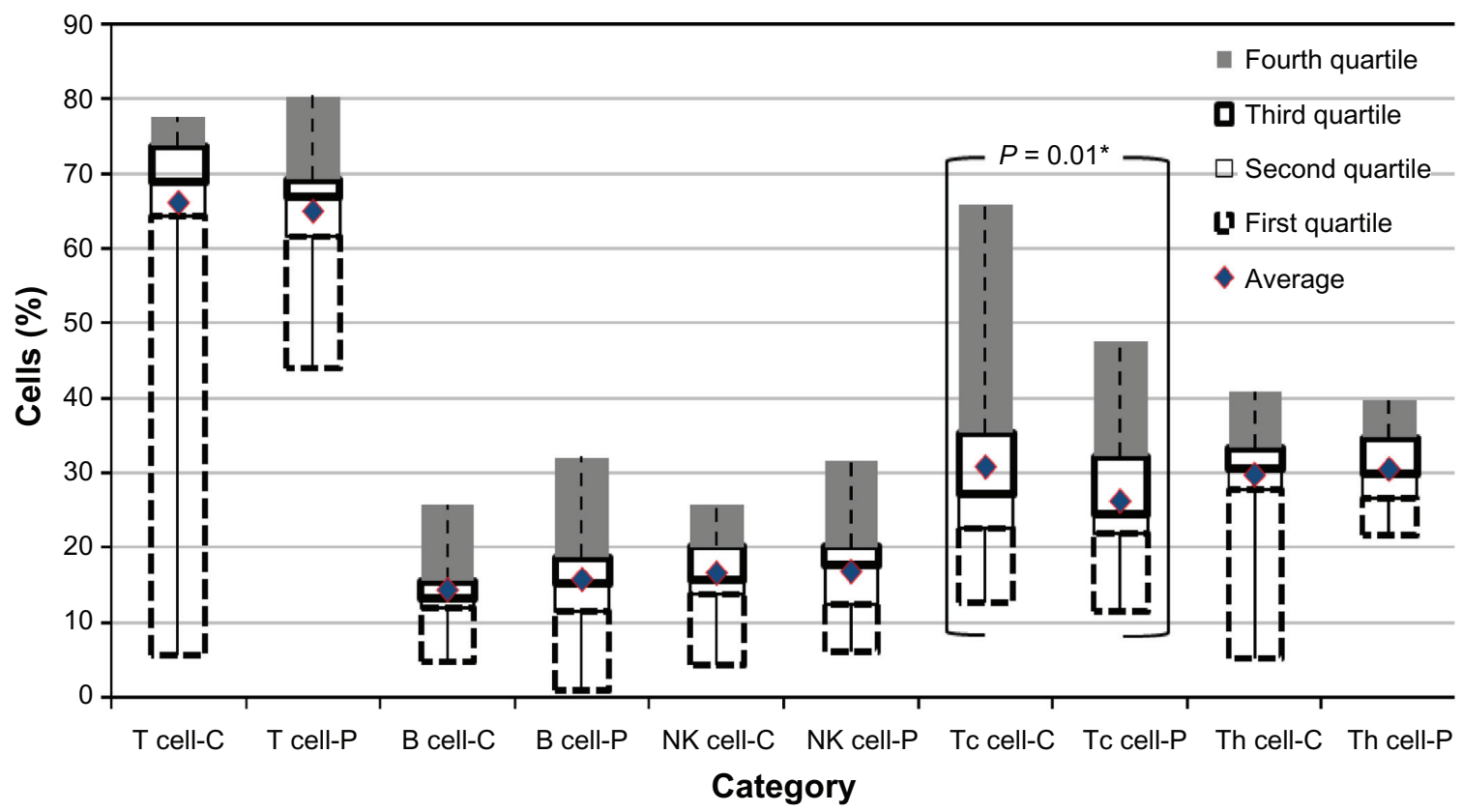

Figure I Peripheral immune cell profile of control $(-C)$ and patients $(-P)$ at baseline.

Notes: *Significant by student's unpaired $t$-test (box-whisker plot). T cell-C-Total T cells from controls; T cell-P-Total T cells from patients; B cell-C-Total B cells from controls; B cell-P-Total B cells from patients; NK cell-C-Total natural killer cells from controls; NK cells-P-Total natural killer cells from patients; Tc cell-C-Cytotoxic T cells from controls; Tc cell-P-Cytotoxic T cells from patients; Th cell-C-Helper T cells from controls; Th cell-P-Helper T cells from patients.

are weak in peripheral blood. ${ }^{17}$ Mainly under the influence of high viral and antigen load, $\mathrm{T}$ cells are attracted into the infected liver where they are diluted among virus-nonspecific $\mathrm{T}$ cells and non-T cells that are the predominant cell population of the intrahepatic infiltrate, resulting in the T cell hyporesponsiveness typical of chronic patients. ${ }^{18,19}$ Furthermore, suppression of $\mathrm{T}$ cell responses is more profound in highly viremic patients, ${ }^{19}$ which is reported to be overcome to some extent by enhanced levels of peripheral blood CD4-mediated T cell reactivity to HBV nucleocapsid antigens. ${ }^{20}$

In the present study, we attempted to evaluate the influence of serum viral load (HBV DNA) and serum HBsAg load on the status of peripheral immunocompetent cells in chronic HBV infection. We found suppression of the total peripheral $T$ cell population, but not of natural killer cells, in our chronic $\mathrm{HBV}$ patients in comparison with healthy controls, indicating
HBV-induced suppression of adaptive immunity, but noninduction of innate immunity in the peripheral lymphocyte pool. Considering the importance of the cytotoxic T cellmediated response for elimination and suppression of HBV replication, ${ }^{19}$ selective depletion of cytotoxic T cells, but not the population of helper T cells, as evident in our patients having a higher viral load ( $>2000 \mathrm{IU} / \mathrm{mL})$, is indicative of persistent chronicity of $\mathrm{HBV}$ infection. However, our data, to some extent, differ from an earlier study that showed decreases in the percentages of CD3+, CD4+ cells, and the ratio of CD4+ cells/CD8+ cells, with an increase in CD8+ cells in chronic HBV infection. ${ }^{21}$ Apart from these, although aspartate transferase and alanine transferase values correlated with serum HBV DNA levels, the concentration of serum HBsAg, viral load, and peripheral immune cell status appeared independent of each other in our study subjects.

Table 2 Comparison of peripheral immune cells profile of control and two groups of HBV-infected subjects at baseline

\begin{tabular}{|c|c|c|c|c|c|c|}
\hline \multirow[t]{2}{*}{ Cell types (\%) } & \multicolumn{6}{|l|}{ Groups } \\
\hline & Controls $(n=21)$ & "Patients-GrI $(\mathrm{n}=12)$ & $P$ value & Controls $(n=21)$ & \$Patients-Gr2 $(n=19)$ & $P$ value \\
\hline T Cells & $68.98 \pm 5.74^{*}$ & $63.5 \pm 6.21^{*}$ & $0.02 *$ & $68.98 \pm 5.74^{*}$ & $64.6 \pm 7.31 *$ & $0.05^{*}$ \\
\hline B Cells & $\mid 4.82 \pm 4.87$ & $16.9 \pm 4.54$ & 0.27 & $14.82 \pm 4.87$ & $16.7 \pm 7.15$ & 0.54 \\
\hline NK Cells & $17.19 \pm 4.45$ & $16.82 \pm 4.35$ & 0.83 & $17.19 \pm 4.45$ & $16.73 \pm 6.06$ & 0.79 \\
\hline $\mathrm{T}_{\mathrm{c}}$ Cells & $31.69 \pm 12.65^{*}$ & $26.22 \pm 5.67$ & 0.204 & $31.69 \pm 12.65^{*}$ & $24.4 I \pm 7.05^{*}$ & $0.046 *$ \\
\hline $\mathrm{T}_{\mathrm{H}}$ Cells & $30.9 \pm 5.28$ & $33 \pm 4.93$ & 0.30 & $30.9 \pm 5.28$ & $30.40 \pm 5.34$ & $0.78 \mathrm{I}$ \\
\hline $\mathrm{T}_{\mathrm{H}}: \mathrm{T}_{\mathrm{c}}$ & $I .114 \pm 0.413$ & $1.32 \pm 0.463$ & 0.208 & $1.114 \pm 0.413$ & $\mathrm{I} .34 \pm 0.44$ & 0.111 \\
\hline
\end{tabular}

Notes: *Significant (Student's unpaired $t$-test); ${ }^{\top V}$ Viral load $<2000 \mathrm{IU} / \mathrm{mL}$; ${ }^{\S}$ Viral load $>2000 \mathrm{IU} / \mathrm{mL}$.

Abbreviations: NK, natural killer; HBV, hepatitis B virus; $T_{c}$, cytotoxic T cells; $T_{H}$, helper T cells; GrI, low viral load group; Gr2, high viral load group. 
Table 3 Comparative cellular, virological, serogical and biochemical parameters of two HBV disease groups based on viral load at baseline

\begin{tabular}{|c|c|c|c|}
\hline Parameters & Viral load $<2000 \mathrm{IU} / \mathrm{mL}(\mathrm{n}=\mathrm{I} 2)$ & Viral load $>2000 \mathrm{IU} / \mathrm{mL}(\mathrm{n}=19)$ & $P$ value \\
\hline T cell & $63.52 \pm 6.2$ & $64.6 \pm 7.3$ & 0.701 \\
\hline$B$ cell & $16.89 \pm 4.54$ & $16.14 \pm 7.39$ & 0.745 \\
\hline NK cell & $16.82 \pm 4.35$ & $16.73 \pm 6.06$ & 0.968 \\
\hline $\mathrm{T}_{\mathrm{C}}$ cell & $26.22 \pm 5.67$ & $24.4 I \pm 7.05$ & 0.501 \\
\hline $\mathrm{T}_{\mathrm{H}}$ cell & $33 \pm 4.93$ & $30.40 \pm 5.34$ & 0.227 \\
\hline $\mathrm{T}_{\mathrm{H}} / \mathrm{T}_{\mathrm{C}}$ & $1.326 \pm 0.46$ & $1.345 \pm 0.44$ & 0.919 \\
\hline Viral load (log DNA copies) & $2.57 \pm 1.13^{*}$ & $4.68 \pm 2.6^{*}$ & $0.0237^{*}$ \\
\hline $\mathrm{HBsAg}(\log \mathrm{IU} / \mathrm{mL})$ & $4.80 \pm 4.62$ & $4.61 \pm 4.59$ & 0.17 \\
\hline ALT (IU/mL) & $24.1 \pm 10.3^{*}$ & $75.8 \pm 54.1^{*}$ & $0.01 *$ \\
\hline AST (IU/mL) & $23.57 \pm 7.13^{*}$ & $39.12 \pm 16.75^{*}$ & $0.01 I^{*}$ \\
\hline
\end{tabular}

Note: *Statistically significant (Student's unpaired $t$-test).

Abbreviations: HBV, hepatitis B virus; NK, natural killer; ALT, alanine transaminase; AST, aspartate transaminase; $H B s A g$, hepatitis B surface antigen; $T_{c}$, cytotoxic T cells; $T_{H}$, helper T cells.

In a previous study, peripheral natural killer cell levels in chronic HBV have been shown to be lower than in controls and, in comparison between patients grouped on the basis of viral load, the level of natural killer cells was significantly lower in patients having a higher viral load $(6.81 \log$ copies $/ \mathrm{mL})$ than those having a lower viral load $(4.81 \log$ copies $/ \mathrm{mL}){ }^{22}$ In contrast, in our study involving lesser viral load, while no alteration was found in the level of natural killer cells compared between patients having lower (2.57 log copies $/ \mathrm{mL}$ ) and higher (4.68 $\log$ copies $/ \mathrm{mL}$ ) viral loads and controls, a significant reduction in cytotoxic $T$ cells was evident in patients having a higher viral load. Although the immunologic cellular mechanism by which the body clears HBV involves specific and nonspecific T lymphocyte responses, ${ }^{23}$ the $\mathrm{HBV}$-specific cellular immune response mounted by the body against the virus has been considered to be an important factor related to viral clearance. ${ }^{24}$ In this respect, one of the limitations of the present study is that we did not determine the percentage of HBV-specific peripheral lymphocytes and this, along with the small sample size, prevent the drawing of a definitive conclusion, and further study along this line is warranted. Quantitative measurement of serum HBsAg based on ELISA and chemiluminescence microparticle assay has been used, ${ }^{25,26}$ which recently gained importance providing level of $\mathrm{HBsAg}$ as a potential marker for monitoring therapeutic responses. ${ }^{12,13}$ Furthermore, the role of serum HBsAg quantification in distinguishing inactive carriers from subjects having the active form of the disease and harboring genotype $\mathrm{D}$ has been implicated in chronic HBV. ${ }^{14}$ Genotype D was predominant in our study subjects, which is in accordance with our previous findings from this part of the country. ${ }^{27}$

The present study is the first of its kind evaluating the relationship between serum HBsAg level, HBV DNA, and peripheral immune cell populations in Indian patients with chronic HBV who are supposed to harbor genotype D. Despite the aforementioned limitations, the present study evidenced a nonassociation of serum HBsAg concentration with serum HBV DNA, as reported earlier. ${ }^{26}$ The study further indicates that, irrespective of serum HBsAg level, HBV suppresses the total $\mathrm{T}$ cell population in the peripheral circulation, and specifically the cytotoxic $\mathrm{T}$ cell population, which was more pronounced in patients having comparatively higher viral load, without altering the status of other cell types or $\mathrm{T}$ cell subsets, reflecting the chronicity of the disease.

\section{Disclosure}

The authors report no conflicts of interest in this work.

\section{References}

1. Bertoletti A, Ferrari C, Fiaccadori F. Role of the cell-mediated immune response in the pathogenesis of hepatitis B virus infection: Possible immunetherapeutic strategies. Acta Biomed Ateneo Parmense. 1996; 67:87-93.

2. Sing G, Butterworth L, Chen X, Bryant A, Cooksley G. Composition of peripheral blood lymphocyte populations during different stages of chronic infection with hepatitis B virus. J Viral Hepat. 1998;5:83-93.

3. Wang KX, Peng JL, Wang XF, Tian Y, Wang J, Li CP. Detection of T lymphocyte subsets and mIL-2R on surface of PBMC in patients with hepatitis B. World J Gastroenterol. 2003;9:2017-2020.

4. Penna A, Chisari FV, Bertoletti A, et al. Cytotoxic T lymphocytes recognize an HLA A2 restricted epitope within the hepatitis B virus nucleocapsid antigen. J Exp Med. 1991;174:1565-1570.

5. Bertoletti A, Ferrari C, Fiaccadori F, et al. HLA class I-restricted human cytotoxic $\mathrm{T}$ cells recognize endogenously synthesized hepatitis B virus nucleocapsid antigen. Proc Natl Acad Sci US A. 1991;88:10445-10449.

6. Sprengers D, van der Molen RG, Kusters JG, et al. Analysis of intrahepatic HBV specific cytotoxic T-cells during and after acute HBV infection in humans. J Hepatol. 2006;45:182-189.

7. Xie DY, Lin BL, Xu QH, et al. Exploration of efficacy predicting indexes of adefovir dipivoxil in the treatment of e-antigen positive chronic hepatitis B. Chin J Hepatol (Chin). 2008;16:341-344.

8. Buti M, Elefeiniotis I, Jardi D, et al. Viral genotype and baseline load predict the response to adefovir treatment in lamivudine-resistant chronic hepatitis B patients. J Hepatol. 2007;47:366-372. 
9. Ciupe SM, Ribeiro RM, Nelson PW, Dusheiko G, Perelson AS. The role of cells refractory to productive infection in acute hepatitis B viral dynamics. Proc Natl Acad Sci U S A. 2007;104:5050-5055.

10. Xuli B, Zhongping D. Advance in viral dynamics of hepatitis B virus infection. Yonsei Med J. 2004;11:36-40.

11. Chan HL, Wong VW, Tse AM, et al. Serum hepatitis B surface antigen quantitation can reflect hepatitis B virus in the liver and predict treatment response. Clin Gastroenterol Hepatol. 2007;5:1462-1468.

12. Brunetto MR, Moriconi F, Bonino F, et al. Hepatitis B virus surface antigen levels: A guide to sustained response to peginterferon alfa-2a in HBeAg negative chronic hepatitis B. Hepatology. 2009;49: $1141-1150$

13. Moucari R, Mackiewicz V, Lada O, et al. Early serum HBsAg drop: A strong predictor of sustained virological response to pegylated interferon alfa-2a in HBeAg-negative patients. Hepatology. 2009;49:115-117.

14. Brunetto MR, Oliveri F, Colombatto P, et al. Hepatitis B surface antigen serum levels help to distinguish active from inactive hepatitis B virus genotype D carriers. Gastroenterology. 2010;139:483-490.

15. Naito H, Hyashi S, Abe K. Rapid and specific genotyping system for hepatitis B virus corresponding to six major genotypes by PCR using type specific primers. J Clin Microbiol. 2001;39:362-364.

16. Biswas R, Tabor E, Hsia CC, et al. Comparative sensitivity of HBV NATs and HBsAg assays for detection of acute HBV infection. Transfusion. 2003;43:788-798

17. Ferrari C, Penna A, Bertoletti A, et al. Cellular immune response to hepatitis $\mathrm{B}$ virus-encoded antigens in acute and chronic hepatitis $\mathrm{B}$ virus infection. J Immunol. 1990;145:3442-3449.

18. Maini MK, Boni C, Lee CK, et al. The role of virus-specific CD8+ cells in liver damage and viral control during persistent hepatitis B virus infection. J Exp Med. 2000;191:1269-1280.
19. Rossol S, Marinos G, Carucci P, Singer MV, Williams R, Naoumov NV. Interleukin-12 induction of Th1 cytokines is important for viral clearance in chronic hepatitis B. J Clin Invest. 1997;99:3025-3033.

20. Guidotti LG, Ando K, Hobbs MV, et al. Cytotoxic T lymphocytes inhibit hepatitis B virus gene expression by a noncytolytic mechanism in transgenic mice. Proc Natl Acad Sci US A. 1994;91:3764-3768.

21. Wang KX, Peng JL, Wang XF, Tian Y, Wang J, Li CP. Detection of T lymphocyte subsets and mIL-2R on surface of PBMC in patients with hepatitis B. World J Gastroenterol. 2003;9:2017-2020.

22. Bing GX, Juan YX, Dong W, Zhong H, Qin XY, Zhong LH. Relationship between serum HBV DNA level and HBV-specific, nonspecific cytotoxic T lymphocytes and natural killer cells in patients with chronic hepatitis B. Chinese Med J. 2009;122:2129-2132.

23. Yan T, Ji W, Wang HF, Zhang AM, Li F. Progresses in studies on immune response of body after hepatitis B virus infection. Foreign Med Epidemiol Infect Dis (Chin). 2004;31:219-222.

24. Hao YH, Yang DL. Advances in research of the mechanism of specific cytotoxic T lymphocytes clear intracellular hepatitis B virus. Chin J Cell Mol Immunol (Chin). 2005;21:128-129.

25. Karakus R, Aral LA, Basturk B, Aybay C. Development of a highly sensitive ELISA for quantification of hepatitis B virus (HBV) surface antigen (HBsAg). Turk J Med Sci. 2007;37:87-92.

26. Wiegand $\mathrm{J}$, Wedemeyer $\mathrm{H}$, Finger A, et al. A decline in hepatitis B virus surface antigen (HBsAg) predicts clearance but does not correlate with quantitative HBeAg or HBV DNA levels. Antivir Ther. 2008;13: 547-554.

27. Mukherjee RM, Balkumar Reddy $P$, et al. Identification of genotype B among hepatitis B virus-infected patients in Hyderabad, India. Ann Hepatol. 2009;8:269-270.
Hepatic Medicine: Evidence and Research

\section{Publish your work in this journal}

Hepatic Medicine: Evidence and Research is an international, peerreviewed, open access journal covering all aspects of adult and pediatric hepatology in the clinic and laboratory including the following topics: Pathology, pathophysiology of hepatic disease; Investigation and treatment of hepatic disease; Pharmacology of drugs used for

\section{Dovepress}

the treatment of hepatic disease. Issues of patient safety and quality of care will also be considered. The manuscript management system is completely online and includes a very quick and fair peer-review system, which is all easy to use. Visit http://www.dovepress.com/ testimonials.php to read real quotes from published authors. 